\title{
Implementing project-based learning to enhance creative thinking skills on water pollution topic
}

\author{
Y. Yamin $a, 1,{ }^{*}$, Anna Permanasari b,2, Sri Redjeki b,3 ${ }^{2}$, and Wahyu Sopandi b,4 \\ a Department of Biology Education, Universitas Pakuan, Jl. Pakuan, Bogor, Jawa Barat 16143, Indonesia \\ Department of Science Education, Sekolah Pascasarjana, Universitas Pendidikan Indonesia, Jl. Dr. Setiabudi No. 229, Bandung, \\ Jawa Barat 40154, Indonesia \\ 1yamin.adisaputra@yahoo.com* ; ${ }^{2}$ anna.permanasari@upi.edu; ${ }^{3}$ sri.redjeki.n@gmail.com; ${ }^{4}$ wsopandi@upi.edu \\ ${ }^{*}$ Corresponding author
}

\begin{tabular}{|c|c|}
\hline ARTICLE INFO & ABSTRACT \\
\hline \multirow[t]{2}{*}{$\begin{array}{l}\text { Article history } \\
\text { Received May 14, } 2020 \\
\text { Revised June 05, } 2020 \\
\text { Accepted June 15, } 2020 \\
\text { Published July 21, } 2020 \\
\text { Keywords } \\
\text { Cretive thinking skills } \\
\text { Environmental problem } \\
\text { Project based learning }\end{array}$} & $\begin{array}{l}\text { The implementation of Project-based learning (PJBL) has been recognized as a } \\
\text { recommended alternative learning to habituate students to solve their daily problems. } \\
\text { This study aimed to describe students' creative thinking skills (CTS) in water pollution } \\
\text { topic using PjBL. The descriptive method was used in this study. The sample in this } \\
\text { study were junior high school students in the Bandung City, Indonesia. The instruments } \\
\text { used in this study were CTS test, peer assessment, and product creativity assessment } \\
\text { rubric. The data gained were analysed using descriptive statistics analysis in terms of } \\
\text { mean and percentage. The results showed that the mean test score of students' CTS } \\
\text { was } 89 \% \text { (excellent category). The achievement of peer assessment indicators was } \\
87 \% \text {, while the performance of product creativity indicators was } 88 \% \text {. This study } \\
\text { concluded that the implementation of PjBL in science learning could improve the CTS of } \\
\text { junior high school students. }\end{array}$ \\
\hline & $\begin{array}{l}\text { Copyright } \odot \text { 2020, Yamin et al } \\
\text { This is an open access article under the CC-BY-SA license }\end{array}$ \\
\hline $\begin{array}{r}\text { How to cite: } \\
\\
\\
\text { creativ } \\
\text { https:/ }\end{array}$ & $\begin{array}{l}\text { A., Redjeki, S., \& Sopandi, W. (2020). Implementing project-based learning to enhance } \\
\text { on water pollution topic. JPBI (Jurnal Pendidikan Biologi Indonesia), 6(2), 225-232. doi: } \\
\text { jpbi.v6i2.12202 }\end{array}$ \\
\hline
\end{tabular}

\section{INTRODUCTION}

In the $21^{\text {st }}$ Century Education with the demands of Sustainable Development Goals (SDGs), integrated science and biology learning is aimed at preparing students to solve various daily life problems (Burbules, Fan, \& Repp, 2020; Laal \& Salamati, 2012). One of the daily problems associated with SDG's and requiring 21st Century skills is environmental issues (Dell'Angelo, D'Odorico, \& Rulli, 2017; Husamah, 2015; Rafaj et al., 2018). It is undeniable, in the current era, environmental problems are still the main problem faced by humans (Alam, 2014; Jianping et al., 2014). Various pollution occurs everywhere, one of which is in water environment (Khatun, 2017; Spanton \& Saputra, 2017). Water pollution categorized as serious environmental problem because it can reduce the availability of clean water and trigger various diseases for local residents (Narendran, 2015). Therefore, integrated science implementation in schools is expected to be one way to increase the students' awareness regarding the problem of water pollution. 
Integrated science learning has been applied in several countries. Several studies conducted to see the effectiveness of the application of integrated science learning. (Idowu, 2011) discussed some of the fundamental problems to develop integrated science curriculum in Nigeria. Other studies investigate the perception of students and teachers of the difficult topics integrated science learning in America (Ogunkola \& Samuel, 2011), Ghana (Ameyaw, 2011), and Nigeria (Edokpayi \& Suleiman, 2011). In the implementation of integrated science learning it needs to be supported by professional teachers who can apply integrated science learning in the classroom well (Hafizan, Halim, \& Meerah, 2012). In addition, it needs to be supported by appropriate learning activities that can stimulate students to be more active in the learning process.

In connection with the integrated science and biology learning role, teachers must be able to empower various thinking skills of their students (Scott, 2015). One of the thinking skills needed by students to solve water pollution problems is creative thinking skills (Birgili, 2015). By having good creative thinking skills, students can trigger students to understand a problem more deeply (Mumford \& Mclntosh, 2017; Vidal, 2010). Their criticality in examining problems has also increased (Hidayati, Zubaidah, Suarsini, \& Praherdhiono, 2019). In addition, they are also able to think flexibly and better determine solutions to problems (King, Goodson, \& Faranak, 2011). In order for these thinking skills to be optimally empowered, learning designs must implement appropriate learning innovations.

One of the learning innovations that has the potential to empower students' thinking skills is Project-based Learning (PjBL) (Bell, 2010; Jensen, 2015; Rambely et al., 2013). PjBL implementation can stimulate students to be actively involved in the learning process (Movahedzadeh, Patwell, Rieker, \& Gonzalez, 2012). PjBL also have an enormous potential to make learning experiences more interesting and meaningful for students (Jensen, 2015). PjBL is also considered to be one of the most promising models for empowering creative thinking skills (Isabekov \& Sadyrova, 2018; Rambely et al., 2013).

The various benefits of PjBL have been further strengthened by the emergence of various studies examining PjBL (Chiang \& Lee, 2016; Wekesa \& Ongunya, 2016). Suryandari, Fatimah, Sajidan, Rahardjo, and Prasetyo (2018) investigated the effectiveness of project-based science learning to enhance pre-service teachers literacy skills and learning creativity in wave and optical materials. Memişoğlu (2011) focused to improve students' success and memorization using PjBL in teaching the "population in our country" unit in the social sciences class. Other studies analyzed the effect of PjBL on student motivation (Chiang \& Lee, 2016); students' engagement (Viswambaran \& Shafeek, 2019), metacognition (Pavkov-Hrvojevic, Obadovic, Cvjeticanin, \& Bogdanovic, 2016), and science process skills (Hernawati, Amin, Irawati, Indriwati, \& Aziz, 2018).

Based on the information conveyed in previous paragraph, research on PjBL is increasingly develop. However, the implementation of PjBL in several countries, such as in Indonesia still not satisfying because this learning is often difficult to implement in the classroom due to several obstacles. The obstacles that can be faced by teacher including time, curriculum, availability of tools/materials and teacher's understanding about PjBL (Kubiatko \& Vaculová, 2011). In addition, those studies also rarely relate the problem of environmental pollution as the basis for student project preparation. Therefore, increasing the frequency of research examining the implementation of PjBL in Indonesia with environmental problems that occur in Indonesia needs to be increased. Therefore, the purpose of this study was to examine the empowerment of students' creative thinking skills through the application of PjBL on the topic of water pollution. This research will provide many benefits such as providing information related to the effectiveness of this learning in empowering the $21^{\text {st }}$ Century skills of Indonesian students. Apart from that, this study can also provide an overview of the obstacles faced when implementing PjBL in Indonesia. In addition, with this research, PjBL dissemination in schools in Indonesia can be increased.

\section{METHOD}

This descriptive research examined the implementation of PjBL in the topic of water pollution. This study begins with need assessment from curriculum expectation. Curriculum was reviewed to determine the aim and competence of learning materials that will be developed, as well as identify the main material that needs to be taught. The next step was the study of literature; carried out by collecting and selecting relevant materials, putting it back together systematically, so that eventually it is acquired the design of learning and research instruments.

The stages of PjBL that implement in this study are shown in Table 1. PjBL implementation was conducted for three face to face meetings. In the first meeting, the stage 1 and 2 were carried out. In the second meeting, the stage 3 and 4 were conducted. In the third meeting, the stage 5 and 5 were finished. 
The research was conducted in 2018. The sample of this study was c 113 seventh grade students who studying in one of junior high schools in. The sample was divided into 4 classes, each class totaling of 28-29 students. To determine student creative thinking skills, creative thinking skills test, peer assessment and product creativity assessment rubrics were chosen as data collection instrument. The test of creative thinking skills consisted from 40 item with two-tier test which consists of the first tier as a multiple choice and the second tier as the reason from the first-tier option. The test of creative thinking skills in this study used indicators of creative thinking skills proposed by Torance, including fluency, flexibility, originality and elaboration (Torrance, 1988), which described in Munandar into several sub-aspects (Munandar, 2004).

Table 1. PJBL implementation in this study

\begin{tabular}{ll}
\multicolumn{1}{c}{ Learning Stages } & \multicolumn{1}{c}{ Activity } \\
\hline Stage 1: Start with the essential question & $\begin{array}{l}\text { In the early stages of PjBL, the students actively answered } \\
\text { questions. } \\
\text { In designing project planning, each group member gave each other } \\
\text { ideas, but students appeared to be a little confused in designing } \\
\text { project planning. } \\
\text { At the stage of arranging schedules, students appeared active and } \\
\text { shared their own ideas well. The project was completed on time } \\
\text { according to a predetermined plan. }\end{array}$ \\
$\begin{array}{l}\text { Monitoring the students and the progress of the project was not only } \\
\text { Stage 3: Create a schedule }\end{array}$ & $\begin{array}{l}\text { carried out during learning but also carried out through media } \\
\text { communication tools such as mobile phones. }\end{array}$ \\
Stage 4: Monitor the students and the progress of the & $\begin{array}{l}\text { The results testing stage was done through product presentations } \\
\text { and tests in front of other students. }\end{array}$ \\
project & $\begin{array}{l}\text { The stage of evaluating the experience was done by asking } \\
\text { questions and sharing experiences during the project creation } \\
\text { process. }\end{array}$ \\
Stage 5: Assess the outcome &
\end{tabular}

Peer assessment contains Yes/No question for each creative thinking skills indicators. The assessment of creativity product consisted of eight indicators including new products, new procedures, products resulted from individual/group interactions with their environment, originality, significance, the accuracy of the application of the science concept in doing projects, relevancy of application of science concept in project creation, and suitability of products made with learning objectives (achievement of basic competencies) (Eragamreddy, 2013). Finally, the data were analyzed by descriptive analysis through the calculation of the percentage of the results of student achievement.

\section{RESULTS AND DISCUSSION}

Meaningful science learning was expected to improve students' creative thinking skills. Students were directed to find solutions to problems faced in everyday life. The theme raised in this study was water pollution. With integrated science learning on the theme of water pollution, students were directed to think creatively to find solutions in an effort to overcome water pollution. The results of the students' creative thinking skills test are presented in Table 2.

Table 2. Creative thinking skills test and peer assessment recapitulation

\begin{tabular}{|c|c|c|}
\hline Indicators & Test & Peer assessment \\
\hline Ability to think smoothly & $87 \%$ & $89 \%$ \\
\hline Ability to think flexibly & $89 \%$ & $85 \%$ \\
\hline Ability to think originally & $92 \%$ & $88 \%$ \\
\hline Ability to specify & $84 \%$ & $91 \%$ \\
\hline Ability to assess (sensitivity) & $85 \%$ & $81 \%$ \\
\hline Curiosity & $91 \%$ & $86 \%$ \\
\hline Imaginative nature & $91 \%$ & $76 \%$ \\
\hline Responsibility for pluralism & $90 \%$ & $83 \%$ \\
\hline Courage to take risks & $89 \%$ & $92 \%$ \\
\hline $\begin{array}{l}\text { toward ideas and opinion } \\
\text { toward the products }\end{array}$ & $96 \%$ & $\begin{array}{l}95 \% \\
97 \%\end{array}$ \\
\hline Average & $89 \%$ & $87 \%$ \\
\hline
\end{tabular}

Based on the percentage of student achievement presented in Table 2, the lowest aspect of creative thinking skills was "ability to specify" indicator, while the highest was "appreciation" indicator. However, even though the "ability to specify" indicator was the lowest, the percentage of student achievement in this aspect 
had reached $84 \%$. Thus, based on the test results, the creative thinking skills of students who have taken PjBL were already in a good category. These results were also in line with the level of students' creative thinking skills when measured using peer-assessment. Furthermore, the percentage range of student achievement in each aspect of creative thinking skills was from 81 to $97 \%$. There were two aspects whose percentage was not optimal, i.e. "new products" and "new procedures" aspect (Table 3). However, the average of indicator achievement based on students' product was reached $88 \%$ (excellent category).

The high level of creative thinking skills of students after participating in PjBL is in line with several previous studies that have also implemented this learning. Some of these studies examine the increase of students' creativity in various countries (Isabekov \& Sadyrova, 2018; Rambely et al., 2013). Several studies in Indonesia also reported similar results (Antika \& Nawawi, 2017; Ummah, Inam, \& Azmi, 2019). The increase in students' creative thinking skills after participating in $\mathrm{PJBL}$ further emphasizes the role of this learning in empowering thinking skills and various other 21st Century competencies (Bell, 2010; Kokotsaki, Menzies, \& Wiggins, 2016; Takeda, 2016). As has been reported in various previous studies, PjBL is included in innovative learning that can empower critical thinking skills (Sasson, Yehuda, \& Malkinson, 2018), science process skills (Hernawati et al., 2018), problem-solving ability (Chiang \& Lee, 2016), and metacognition (Pavkov-Hrvojevic et al., 2016).

Table 3. Recapitulation of product creativity achievement

\begin{tabular}{lc}
\hline \multicolumn{1}{c}{ Indicators } & Indicators Achievement \\
\hline New products & $67 \%$ \\
New procedures & $67 \%$ \\
Products resulted from individual/group interactions with their environment & $93 \%$ \\
Originality & $100 \%$ \\
Significance & $87 \%$ \\
The accuracy of the application of the science concept in doing projects & $93 \%$ \\
Relevancy of application of science concept in project creation & $93 \%$ \\
Suitability of products made with learning objectives (achievement of basic competencies) & $100 \%$ \\
\hline \multicolumn{1}{c}{ Average } & $\mathbf{8 8 \%}$ \\
\hline
\end{tabular}

The effectiveness of empowering creative thinking skills through PjBL is caused by the characteristics and variety of learning activities in this learning. By implementing PjBL in integrated science learning, students will be immediately facilitated in dealing with contextual problems (Chen \& Yang, 2019; Musa, Mufti, Latiff, \& Amin, 2011) and trained creatively to solve these problems (Isabekov \& Sadyrova, 2018; Sumarni, 2013). In this study, water pollution was raised as the main problem that had to be solved by students. Products designed by students were the solution to the problems faced, which was water filters. Students were divided into four groups. Each group was given the freedom to determine the materials and methods used to make water filters according to their creativity. After that they explained and tested the products they had made. Documentation of product presentation and trial can be illustrated in Figure 1. Figure 1 showed that students designed water filtration from (a) mesocarp and charcoal; (b) gravel and charcoal; (c) sand, mesocarp and gravel; (d) sand and mesocarp. Each group used different materials for water filter but visually the water produced by all groups looks clear. Mesocarp, charcoal, and gravel removed suspended solid particles and water permeates through a bed of granular media.

Project activity provided an real environment condition for students to develop their creative thinking skills. Students will try to find solutions for the problems they face in any way and from their own will. Moreover, this approach supports students in acquiring manual skills and by performing authentic activities. The creative process can be undertaken for any project or task in which we are challenged to come up with a unique product or result to solve a problem or reach a goal (Eragamreddy, 2013) The problem of water pollution challenged the students to engage actively design a product to solve problem. In such challenging situations, students are fostered to use their creativity during designing the product. Through PjBL, students not only identify problems and find solutions to problems faced, but students also required combining knowledge and creative thinking skills to solve the problems (Isabekov \& Sadyrova, 2018; Sumarni, 2013). PjBL has also facilitated students to develop themselves both academically and practically to find solutions in daily life (Husamah, 2015; Kubiatko \& Vaculová, 2011). 


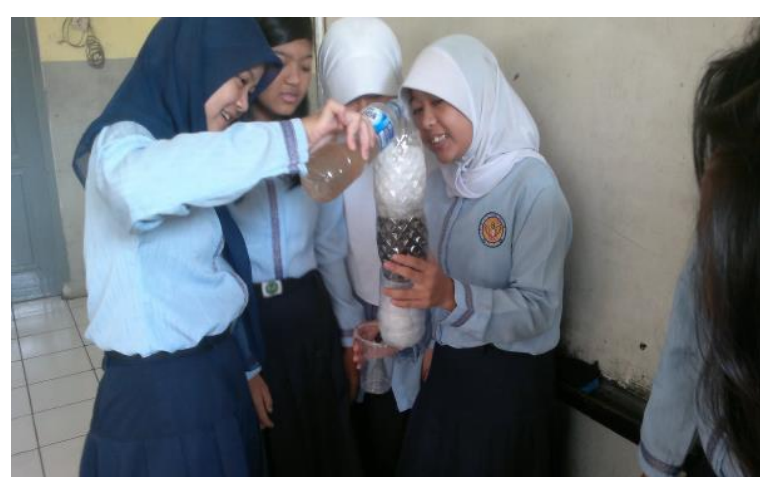

(a)

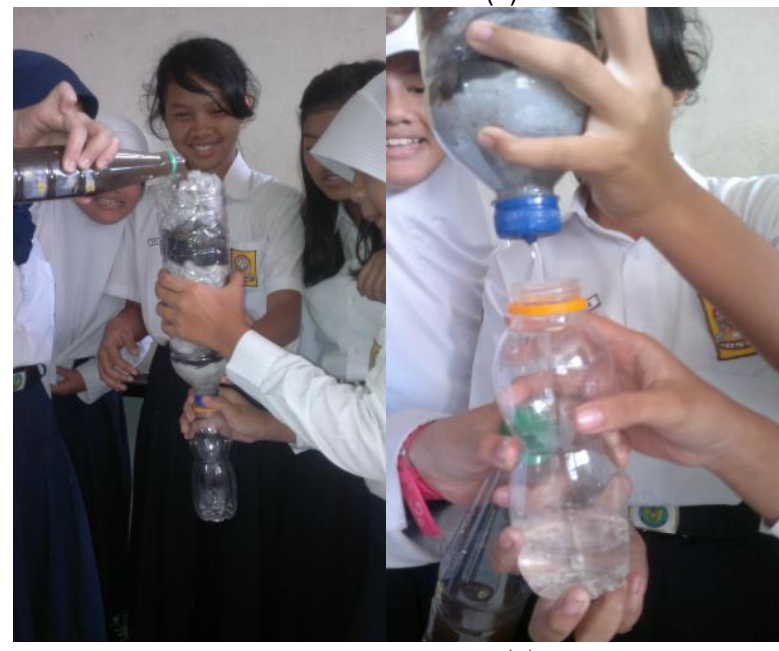

(c)

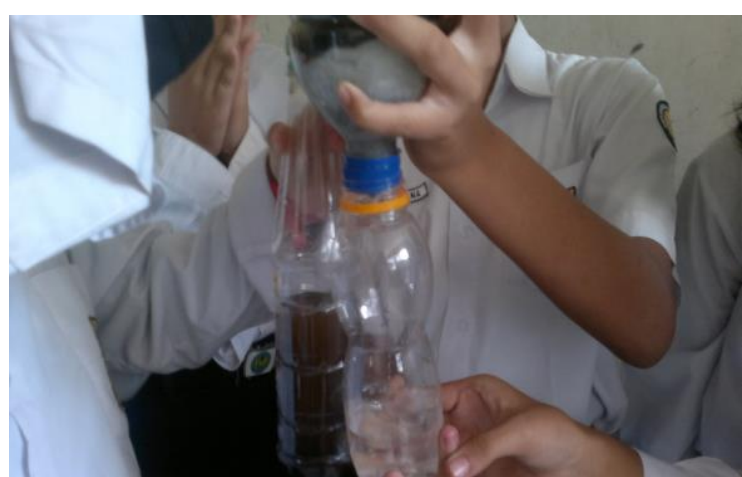

(b)

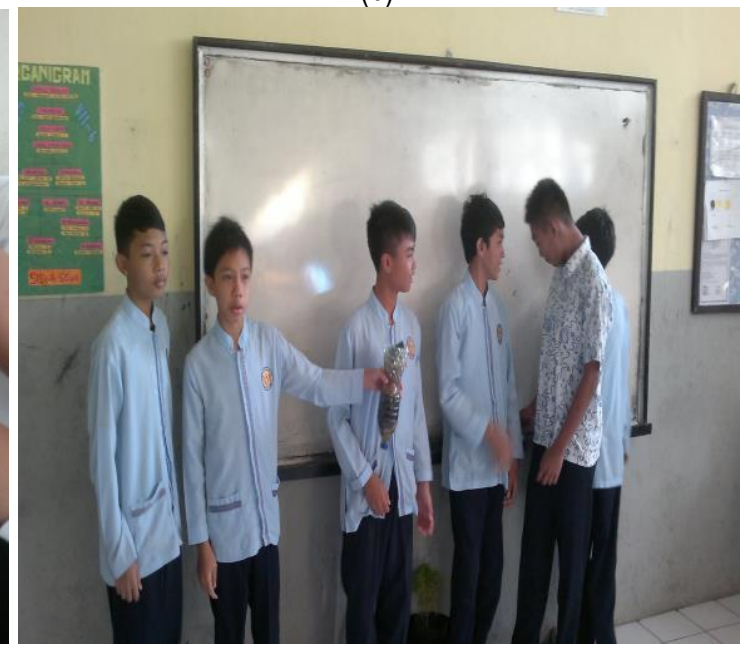

(d)

Figure 1. Documentation of product presentation and trial in (a) group $A$, (b) group $B,(c)$ group $C$, and group $D$

Based on the findings of this study, PJBL provides optimal benefits for developing student creativity. Creativity as an indicator of high creative thinking skills is a competency that must be optimally empowered in the current era (Guo, 2016; Lee \& Carpenter, 2015). Together with critical thinking, communication and collaborative skills, creative thinking skills are classified as 4 C competencies (Guo, 2016) which are seen as one of the main competency groups in the 21st century (Lee \& Carpenter, 2015). Given the high implementation of conventional learning in various schools in Indonesia, socialization and innovative learning training such as $\mathrm{PJBL}$ is necessary carried out continuously.

\section{CONCLUSION}

This study conclude that PjBL implementation would help students develop creative thinking skills. Student could improve their creative thinking skills through product design activities as their effort to solve the problem they face. The empowerment of students 'creative thinking skills is evidenced by the high percentage of achievement of students' creative thinking skills, both by means of measuring tests, peer assessments, and product assessments.

Given the high benefits of PjBL, the application of this learning should be more massive in Indonesia. The government and policy makers are expected to be able to hold various trainings and socializations related to the benefits and ways of teaching integrated science learning using PjBL. Various studies examining PjBL also need to be carried out continuously in order to provide more information regarding the benefits of this learning.

\section{ACKNOWLEDGMENT}

The authors gratefully acknowledge financial support from Pakuan University. 


\section{REFERENCES}

Alam, S. (2014). Globalization, poverty and environmental degradation: Sustainable development in Pakistan. Journal of Sustainable Development, 3(3), 103-114. doi: https://doi.org/10.5539/jsd.v3n3p103

Ameyaw, Y. (2011). Environmental pedagogies that promote students understanding of integrated science (biologi aspect). Journal of Education, 1(1), 10-15. Retrieved from https://bioinfopublication.org/files larticles/1_1_2 JED.pdf

Antika, R. N., \& Nawawi, S. (2017). Pengaruh model project based learning pada mata kuliah seminar terhadap keterampilan berpikir kreatif mahasiswa. JPBI (Jurnal Pendidikan Biologi Indonesia), 3(1), 72 79. doi: https://doi.org/10.22219/jpbi.v3i1.3905

Bell, S. (2010). Project-based learning for the 21st Century: Skills for the future. The Clearing House: $A$ Journal of Educational Strategies, Issues and Ideas, 83(2), 39-3. doi: https://doi.org/10.1080/000986 50903505415

Birgili, B. (2015). Creative and critical thinking skills in problem-based learning environments. Journal of Gifted Education and Creativity, 2(2), 71-80. doi: https://doi.org/10.18200/JGEDC.2015214253

Burbules, N. C., Fan, G., \& Repp, P. (2020). Five trends of education and technology in a sustainable future. Geography and Sustainability, 1(2), 93-97. doi: https://doi.org/10.1016/j.geosus.2020.05.001

Chen, C.-H., \& Yang, Y.-C. (2019). Revisiting the effects of project-based learning on students' academic achievement: A meta-analysis investigating moderators. Educational Research Review, 26, 71-81. doi: https://doi.org/10.1016/j.edurev.2018.11.001

Chiang, C. L., \& Lee, H. (2016). The effect of project-based learning on learning motivation and problemsolving ability of vocational high school students. International Journal of Information and Education Technology, 6(9), 709-712. doi: https://doi.org/10.7763/IJIET.2016.V6.779

Dell'Angelo, J., D'Odorico, P., \& Rulli, M. C. (2017). Threats to sustainable development posed by land and water grabbing. Current Opinion in Environmental Sustainability, 26-27, 120-128. doi: https://doi.org/ 10.1016/j.cosust.2017.07.007

Edokpayi, J. N., \& Suleiman, M. A. (2011). Students integrated science achievement as predicator of later achievement in chemistry: A case study among selected secondary schools in Zaria metropolis. Archives of Applied Science Research, 3(4), 527-535. Retrieved from https://www.researchgate.net/ publication/283299571\%0AStudents

Eragamreddy, N. (2013). Teaching creative thinking skills. International Journal of English Language \& Translation Studies, 1(2), 124-145. Retrieved from https://s3.amazonaws.com/academia.edu.document s/31884760

Guo, Z. (2016). The cultivation of $4 \mathrm{C}$ 's in China - Critical thinking, communication, collaboration and creativity. In International Conference on Education, Management and Applied Social Science. Beijing. Retrieved from http://www.dpi-proceedings.com/index.php/dtssehs/article/download/6796/6388

Hafizan, E., Halim, L., \& Meerah, T. S. (2012). Perception, conceptual knowledge and competency level of integrated science process skill towards planning a professional enhancement programme. Sains Malaysiana, 41(7), 921-930. Retrieved from http://journalarticle.ukm.my/5307/1/16\%2520Edy\%2520 Hafizan.pdf

Hernawati, D., Amin, M., Irawati, M., Indriwati, S., \& Aziz, M. (2018). Integration of project activity to enhance the scientific process skill and self-efficacy in Zoology of Vertebrate Teaching and Learning. EURASIA Journal of Mathematics, Science and Technology Education, 14(6), 2475-2485. doi: https://doi.org/10. 29333/ejmste/89940

Hidayati, N., Zubaidah, S., Suarsini, E., \& Praherdhiono, H. (2019). Examining the relationship between creativity and critical thinking through integrated problem-based learning and digital mind maps. Universal Journal of Educational Research, 7(9A), 171-179. doi: https://doi.org/10.13189/ujer.2019.07 1620

Husamah, H. (2015). Thinking skills for environmental sustainability perspective of new students of biology education department through blended project based learning model. Jurnal Pendidikan IPA Indonesia, 4(2), 110-119. doi: https://doi.org/10.15294/jpii.v4i2.3878

Idowu, D. (2011). Developing Nigerian integrated science curriculum. Journal of Soil Science and Environmental Management, 2(8), 134-145. Retrieved from http://www.academicjournals.org/JSSEM

Isabekov, A., \& Sadyrova, G. (2018). Project-based learning to develop creative abilities in students. In J. Drummer, G. Hakimov, M. Joldoshov, T. Köhler, \& S. Udartseva (Eds.), Vocational Teacher Education 
in Central Asia: Developing Skills and Facilitating Success (pp. 43-49). Cham: Springer International Publishing. doi: https://doi.org/10.1007/978-3-319-73093-6_4

Jensen, K. J. (2015). A meta-analysis of the effects of problem and project-based learning on academic achievement in grades 6-12 populations, (May). doi: https://doi.org/10.3102/00346543067001043

Jianping, L., Minrong, L., Jinnan, W., Jianjian, L., Hongwen, S., \& Maoxing, H. (2014). Global environmental issues and human wellbeing. In L. Jianping, L. Minrong, W. Jinnan, L. Jianjian, S. Hongwen, \& H. Maoxing (Eds.), Report on Global Environmental Competitiveness (2013) (pp. 3-21). Berlin: Springer. doi: https://doi.org/10.1007/978-3-642-54678-5_1

Khatun, R. (2017). Water pollution: Causes, consequences, prevention method and role of WBPHED with special reference from Murshidabad District. International Journal of Scientific and Research Publications, 7(8), 269-2250. Retrieved from http://www.ijsrp.org/research-paper-0817/ijsrp-p6832.pdf

King, F. J., Goodson, L., \& Faranak, R. (2011). Higher order thinking skills: Definition, teaching strategies and assessment. Tallahassee. Retrieved from https://www.academia.edu/19759607/HIGHER_ORDER_ THINKING_SKILLS

Kokotsaki, D., Menzies, V., \& Wiggins, A. (2016). Project-based learning: A review of the literature. Improving Schools, 19(3), 267-277. doi: https://doi.org/10.1177/1365480216659733

Kubiatko, M., \& Vaculová, I. (2011). Project-based learning: Characteristic and the experiences with application in the science subjects. Energy Education Science and Technology Part B: Social and Educational Studies, 3(1), 65-74. Retrieved from https://pdfs.semanticscholar.org/9ea0/94d66438a7 d5f034354db95827d9dd8b17d2.pdf

Laal, M., \& Salamati, P. (2012). Lifelong learning; why do we need it? In Procedia - Social and Behavioral Sciences (Vol. 31, pp. 399-403). doi: https://doi.org/10.1016/j.sbspro.2011.12.073

Lee, S., \& Carpenter, R. (2015). Creative thinking for 21 st century composing practices: Creativity pedagogies across disciplines. Across the Disciplines, 12(4). Retrieved from https://wac.colostate.edu/atd/per forming_arts/lee_carpenter2015.cfm

Memişoğlu, H. (2011). The effect of project based learning approach in social sciences class on the Student success and memorability. International Journal of Humanities and Social Science, 1(21), 295-307. Retrieved from http://www.ijhssnet.com/journals/Vol_1_No_21_Special_Issue_December_2011/33.pdf

Movahedzadeh, F., Patwell, R., Rieker, J. E., \& Gonzalez, T. (2012). Project-based learning to promote effective learning in biotechnology courses. Education Research International, 2012, 1-8. doi: https:/l doi.org/10.1155/2012/536024

Mumford, M. D., \& McIntosh, T. (2017). Creative thinking processes: The past and the future. Journal of Creative Behavior, 51(4), 317-322. doi: https://doi.org/10.1002/jocb.197

Munandar, U. (2004). Pengembangan kreativitas anak berbakat. Jakarta: Rineka Cipta. Retrieved from https://opac. perpusnas.go.id/DetailOpac. aspx?id=661520

Musa, F., Mufti, N., Latiff, R. A., \& Amin, M. M. (2011). Project-based learning: Promoting meaningful language learning for workplace skills. In Procedia - Social and Behavioral Sciences (Vol. 18, pp. 187195). doi: https://doi.org/10.1016/j.sbspro.2011.05.027

Narendran, N. (2015). A review on environmental problem due to water pollution. International Journal of Scientific Engineering and Research (IJSER), 3(4), 2014-2016. Retrieved from http://www.ijser.in/ archives/v3i4/IJSER1570.pdf

Ogunkola, B., \& Samuel, D. (2011). Science teachers' and students' perceived difficult topics in the integrated science curriculum of lower secondary schools in Barbados. World Journal of Education, 1(2), 17-29. doi: https://doi.org/10.5430/wje.v1n2p17

Pavkov-Hrvojevic, M., Obadovic, D. Ž., Cvjeticanin, S., \& Bogdanovic, I. (2016). Fostering pimary school students' metacognition using project-based learning. In The Eurasia Proceedings of Educational \& Social Sciences (Vol. 4, pp. 123-126). Retrieved from http://dergipark.gov.tr/download/articlefile/332252

Rafaj, P., Kiesewetter, G., Gül, T., Schöpp, W., Cofala, J., Klimont, Z., ... Cozzi, L. (2018). Outlook for clean air in the context of sustainable development goals. Global Environmental Change, 53, 1-11. doi: https://doi.org/10.1016/j.gloenvcha.2018.08.008

Rambely, A. S., Ahmad, R. R., Majid, N., M-Suradi, N. R., Din, U. K. S., A-Rahman, I., ... Abu-Hanifah, S. (2013). Project-based activity: Root of research and creative thinking. International Education Studies, 6(6), 66-71. doi: https://doi.org/10.5539/ies.v6n6p8

Sasson, I., Yehuda, I., \& Malkinson, N. (2018). Fostering the skills of critical thinking and question-posing in a 
project-based learning environment. Thinking Skills and Creativity, 29, 203-212. doi: https://doi.org/10.1016/j.tsc.2018.08.001

Scott, C. L. (2015). The futures of learning 2: What kind of learning for the 21st century? (No. 14). Ireland. Retrieved from https://www.researchgate.net/profile/Dickson_Adom/post/How_to

Spanton, P. I., \& Saputra, A. A. (2017). Analysis of sea water pollution in coastal marine district tuban to the quality standards of sea water with using storet method. Jurnal Kelautan, 10(1), 103-112. Retrieved from http://journal.trunojoyo.ac.id/jurnalkelautan/article/view/2671

Sumarni, W. (2013). The strengths and weaknesses of the implementation of project based learning: A review. International Journal of Science and Research, 4(3), 2319-7064. Retrieved from https:/l www.ijsr.net/archive/v4i3/SUB152023.pdf

Suryandari, K. C., Fatimah, S., Sajidan, S., Rahardjo, S. B., \& Prasetyo, Z. K. (2018). The impact of projectbased learning approach in science education on pre-service teachers' attitudes for science and project. Jurnal Cakrawala Pendidikan, 37(3), 71-80. doi: https://doi.org/10.21831/cp.v38i3.17229

Takeda, I. (2016). Report: Project-based learning with 21st century skills for the Japanese language classroom. Journal of Integrated Creative Studies, 1-7. Retrieved from http://www2.yukawa.kyotou.ac.jp/ future/wp-content/uploads/2017/12/2016-020-e.pdf

Torrance, E. P. (1988). The nature of creativity as manifest in its testing. In Contemporary psychological perspectives (pp. 43-75). Cambridge University Press. Retrieved from https://psycnet.apa.org/record/ 1988-98009-002

Ummah, S. K., Inam, A., \& Azmi, R. D. (2019). Creating manipulatives: Improving students' creativity through project-based learning. Journal on Mathematics Education, 10(1), 93-102. doi: https://doi.org/10.22342/ jme.10.1.5093.93-102

Vidal, R. V. V. (2010). Creative problem solving: An applied university course. Pesquisa Operacional, 30(2), 405-426. doi: https://doi.org/10.1590/S0101-74382010000200009

Viswambaran, V. K., \& Shafeek, S. (2019). Project based learning (PBL) approach for improving the student engagement in vocational education: An investigation on students' learning. In 2019 Advances in Science and Engineering Technology International Conferences (ASET) (pp. 1-8). IEEE. doi: https://doi.org/10.1109/ICASET.2019.8714463

Wekesa, N. W., \& Ongunya, R. O. (2016). Project based learning on students' performance in the concept of classification of organisms among secondary schools in Kenya. Journal of Education and Practice, 7(16), 25-31. Retrieved from https://files.eric.ed.gov/fulltext/EJ1105278.pdf 